\title{
Comparing Exceptionalism in France and the USA
}

A Transatlantic Approach to the Death Penalty Abolition Debate (1972-1977)

\section{Elsa Devienne}

\section{(2) OpenEdition}

\section{Journals}

Electronic version

URL: https://journals.openedition.org/ejas/7745

DOI: $10.4000 /$ ejas. 7745

ISSN: 1991-9336

Publisher

European Association for American Studies

\section{Electronic reference}

Elsa Devienne, "Comparing Exceptionalism in France and the USA", European journal of American studies [Online], 5-1 | 2010, document 1, Online since 29 January 2010, connection on 08 July 2021. URL: http://journals.openedition.org/ejas/7745 ; DOI: https://doi.org/10.4000/ejas.7745

This text was automatically generated on 8 July 2021.

Creative Commons License 


\title{
Comparing Exceptionalism in France and the USA
}

\author{
A Transatlantic Approach to the Death Penalty Abolition Debate \\ (1972-1977)
}

Elsa Devienne

\section{Introduction}

1 "Sustained, systematic, organized, and relentless." As Denis Lacorne has recently pointed out, European media have unremittingly led the denunciation campaign of the death penalty in the United States throughout the 1990s and 2000s. France, in particular, has criticized the use of capital punishment in the American legal system resulting, ironically, in some American death-row inmates' life stories finding their ways into French newspapers more easily than into their American equivalents. ${ }^{1}$ Numerous legal scholars and scientists have tried to theorize and decipher this "widening divide" between Europe and the "American exception." 2 However, the notion of exceptionalism does not take into account the recent transatlantic history of the abolition debate and effaces the period during which the purported exceptionalism was not American but French. ${ }^{3}$ Although an "exception" repeatedly decried by its European neighbors for most of the 1970s, France has now removed capital punishment not only from its laws but also from its national "imaginary." ${ }^{4}$ Historical scholarship on the history of the death penalty in France tends to reflect this obliviousness by emphasizing the inevitability of the 1981 abolition. ${ }^{5}$ Similarly, collective memory tends to be excessively short regarding the guillotine: not so long ago, while the electric chair was collecting dust, the guillotine was still executing the condemned.

2 In this article, I intend to look closely at the short period in the 1970s when American executions were halted while in France the executions continued in cases that were widely debated in public opinion. ${ }^{6}$ By examining this intriguing moment in the transatlantic history of capital punishment, this essay follows a recent trend in the history of the death penalty. By erasing the traditional boundaries between national histories, it seeks to detect the rise of an "international judicial and political discourse on the penalty of death and its abolition."7 The article focuses on the reception of the 
two major decisions taken by the Supreme Court in the 1970s and their direct consequences, as they were reported in the main French newspapers and television news magazines. ${ }^{8}$ However, this essay is not solely about the French gaze on American practices. The journalists actively used American decisions to stoke the national debate by reading their meanings in light of the French context. While for a short period the United States occupied the position of exemplary "civilized" nation-thereby complicating the traditional scholarship on Franco-American relations largely preoccupied with anti-Americanism-this situation was soon reversed with the reinstatement of the death penalty in the US in 1976 and the Patrick Henry trial in 1977 that seemed to presage abolition in France. By tracing the progressive emergence of an official discourse on the death penalty as an aberration in French history, even before the actual law of 1981, the article demonstrates how French media gradually constructed the contemporary opposition between a death-penalty free France and a "barbaric" America. ${ }^{9}$

II. The 1972 Supreme Court Decisions and their Reception in France

3 On June 29 1972, in a group of cases collectively called Furman v. Georgia, the Supreme Court declared every existing death penalty law in the United States unconstitutional on the grounds that they violated the "cruel and unusual punishment" clause of the Eighth Amendment. This decision, which effectively put a moratorium on capital punishment, was "one of the biggest surprises in its history" 10 and the result of a complex combination of factors. While Herbert Haines emphasizes the "inspirational' effect" of Supreme Court decisions in other arenas like Civil Rights, most scholars cite the constitutional attack on capital punishment led by the lawyers of the National Association for the Advancement of Colored People's Legal Defence Fund and the American Civil Liberties Union since the beginning of the 1960s. ${ }^{11}$ That exact same day, a "few hours away" as Le Monde put it, French inmates Claude Buffet and Roger Bontems were condemned to death in one of the most controversial trials of the decade..$^{12}$ In 1971 while serving their sentence in the Clairvaux prison, the two inmates had taken a prison guard and a nurse hostage, and eventually killed them both. ${ }^{13}$ As no execution had taken place in France since 1969, the sentence elicited a renewed interest in the abolition question. This historical coincidence, far from being ignored or dismissed as irrelevant to the national debate, forced French journalists in June 1972 to raise questions concerning the issue of the death penalty in a transatlantic, if not global, perspective.

4 Significantly, the French media reported these two news items simultaneously, subsequently transforming their reportage into an opportunity to discuss the abolition debate from an international point of view. Most newspapers not only noted the coincidence and emphasized the significance of the two decisions on their front pages, but also broadened the perspective and defined the controversy in global terms. ${ }^{14}$ In Le Figaro of June 30 1972, the coincidence was highlighted as follows: "At the same moment when the assizes court of Aube was condemning the two criminals to the death sentence, the Supreme Court decides that capital punishment cannot be applied." ${ }^{15}$ According to La Croix, the French Catholic newspaper, "the coincidence cannot be missed" and the two events contributed "to put[ting] the death penalty on the agenda", while for Le Monde they "relaunch[ed] the controversy." ${ }^{16}$ Both Le Monde and France Soir highlighted the symbolic value of the coincidence, and ran a special article on the international state of abolition. "The United States is joining the more than thirty countries in the world that have abolished the death penalty" announced Le 
Monde ${ }^{17}$ However, the abolition was not the only issue framed in global terms: the factors explaining strong public support for the death penalty-as exemplified by the applause and cheers at Buffet-Bontems' verdict-appeared to be the same in France and in the United States. Quoting the American pundit George Gallup's analysis of the American situation, the magazine Le Point identified the growth in criminality as the main reason for the increasing support for capital punishment in France. ${ }^{18}$

5 According to some newspapers, the issue was not only international, it was also, on a more philosophical level, linked with a "civilizing process." ${ }^{19}$ Le Figaro argued that the two events "relaunch[ed] this never-ending debate around this great and mysterious problem that has taken place in every civilized society." Similarly, La Croix was concerned by this "old and serious debate that no civilized society can evade," and elaborated the issue further: "Does the collectivity have the right to kill those who have transgressed the law?" ${ }^{20}$ The notion of "civilization" was invoked in the death penalty debate as early as the late eighteenth century. It was used to promote moving executions to the jail yard, away from the public eye, as well as other methods of punishment that officials and reformers considered more "humane." Even proponents of the death penalty have invoked the discourse of "civilization" to argue for the compatibility of the ultimate punishment with the process of civilization. In contrast, used in connection with other concepts such as "humanization" and "progress," it has also allowed death penalty detractors to imagine and promote a teleological process towards abolition. ${ }^{21}$ The term thus needs to be historicized to cover how it evolved according to geographical and historical contexts.

6 What defines "civilization" in these 1972 reports is the capacity for a society to at least broach the issue of the retention or abolition of the death penalty. All "civilized societies" are bound to confront this question. Nevertheless both Le Figaro and La Croix are both neutral on the issue of abolition (the French right, which Le Figaro represented, was divided on the topic, while the Catholic church had not yet taken a definite position). ${ }^{22}$ They therefore did not embrace the discourse, especially prevalent after World War II, that identifies a civilized process leading inexorably to the rejection of legalized state killing. More cautious in their use of the phrase "civilized society", they simply acknowledged the shared conundrum present in American and French societies. ${ }^{23}$ This more philosophical outlook adopted by both newspapers contributed to the international discourse on the penal system.

7 While the French newspapers internationalized the issue, the immediate impact of the American abolition on the national debate in France was at the same time highlighted. During the 1970s, the French media played a central role in mobilising a major public debate on abolition. Partisans of abolition and their adversaries consistently discussed sensational cases through op-eds and opinion columns. ${ }^{24}$ In this heated context, it is no surprise that the journalists used the Supreme Court decision as fodder to ignite the French debate. According to Le Monde, the coincidence "rejuvenate[d] the debate on the retention or the abolition of the death penalty in France." As the newspaper was largely in favor of abolition, the Supreme Court decision was exploited to strengthen the abolitionist side. The journalist argued that the question of abolition was posed in "identical terms in the United States" and that criminals "as revolting as Buffet and Bontems" like "Charles Manson and his accomplices" would serve their sentences in jail, just as the French criminals could in "the prison of Mende ${ }^{25}$." In other words, the same questions, the same arguments, and the same debate in both countries, should 
have begotten the same resolution: abolition. Hinting at Georges Pompidou's wellknown repulsion for the death penalty, the journalist emphasized the coincidence by asserting that "what the Supreme Court has decided, Mr. Pompidou was ready to do just before the Clairvaux drama." ${ }^{26}$ The newspaper was not only reporting information; it stressed the divergent path of the two countries, and the straight comparison tarnished France's image. Similarly, L'Express had reservations concerning the "preventive value of the ultimate punishment" in the case of Buffet and Bontems, both re-offenders: "Its exemplarity seems rather illusory. This is also the opinion of the American Supreme Court that has just abolished the death penalty." ${ }^{27}$ The journalist hinted at one of the most cherished arguments used by the partisans of capital punishment: its purported deterrence effect. The Buffet and Bontems affair seemed to belie the efficiency of such an effect: they both knew that they could be executed if they were caught but they had decided to take the risk regardless. If the threat of the guillotine did not deter inmates from repeating their crimes, the journalist from L'Express implied, then the punishment seemed devoid of most of its legitimacy. The American Supreme Court was merely acknowledging this state of affairs by abolishing the death penalty.

8 Becoming an integral part of the French debate, the American decision was even used by French journalists as a means to pressure the French president. Indeed, in Le Canard enchainé, the American decision was one more argument for clemency-the exclusive domain of the president-being applied in the Buffet-Bontems case. The Canard addressed the article to President Pompidou: "You, the man of the last resort...What are you going to decide? Will you yield to the lynching mob or will you pardon the 'Enraged of Clairvaux'? Destiny is making it simple for you. In the United States of America where justice has never been easy on its criminals ... the death penalty has just been abolished forever. If I were you, Mr. President, ... I would take advantage of this example to order the Senate to put the guillotine away." ${ }^{28}$ In contrast to La Croix and Le Figaro, the Canard was implicitly taking up the discourse that identifies "civilization" with the rejection of capital punishment. By equating the behavior of the public in the Buffet-Bontems trial with the irrationality of a "lynching mob", the newspaper's intent was to induce shame among officials, thereby influencing their choice. This tactic was not only adopted by journalists but also by famous abolitionists like lawyer Albert Naud. On June 29, as quoted by France Soir, Naud shouted out: "Great victory for the society indeed. Sending Claude Buffet to the guillotine! A man good for psychiatry!" He then emphasized the symbolic damage the decision imposed on the reputation of "Voltaire and Hugo's country." But above all, he asserted that "the height of shame for our country is that the sentence was pronounced the same day that the Supreme Court abolished the death penalty in the United States." ${ }^{29}$ Naud exploited the lasting rivalry between France and the United States as to which country could claim to be the beacon of the free world. France, he implied, was losing ground. ${ }^{30}$

III The US as Exemplary Nation

9 To stir up the feeling that France was taking the wrong path, French media represented the United States as an exemplary nation. Indeed, in the words of Le Canard it constituted "an example" that Pompidou should follow. This attitude strongly undermined the prevalent beliefs of the French public about the American penal system. Indeed, France-and for that matter European countries in general-have a long tradition of putting America "on trial" when it comes to its penal system. ${ }^{31}$ While the United State could pride themselves on having a far more gentle penal code than 
Europe in the nineteenth century, the situation was reversed in the twentieth. Starting in the 1920s with the Sacco and Vanzetti case, then followed by the Rosenbergs' death sentence and the execution of Caryl Chessman, Europe harshly criticized American use of capital punishment..$^{32}$ However, the decision of 1972 seemed to turn the tables all over again. The sudden admiration for the American penal system was not only observable in right-wing newspapers, but also in the leftist ones as exemplified by the relatively positive depiction in Le Canard. The article in Le Monde reporting on abolition similarly ended with praise for the Court's ability to judge the issue not on criminological or penal grounds but as a philosophical question. "Do we still have to wait?" asked the journalist - "What gesture would indeed be less demagogic, more courageous, than the decision to put an end to what is not a sentence but a torture, not a penal sanction but a residue of barbarism?" ${ }^{33}$ In this instance, while the United States was on the side of rationalism and humanitarianism, France was implicitly associated with backwardness and cruelty.

10 As evidenced by many book titles ("The Anti-American Obsession", "The American Enemy"), the abundant scholarly literature on Franco-American relationships largely focuses on the phenomenon of anti-Americanism. ${ }^{34}$ Nevertheless, this seemingly unexpected praise for American penal practices remains consistent with the paradoxical nature of French anti-Americanism. According to Denis Lacorne, the "discourses" that form anti-Americanism are characterized by "ambiguity and frequent contradictions." "Subject to frequent swings," they evolve depending on the immediate historical context. ${ }^{35}$ Negative opinions can also accommodate themselves with contemporaneous positive appreciations of the United States, as is patently clear in this case. While Le Canard exhorted Pompidou to imitate the American Supreme Court, it criticized in the same movement the American penal system by lampooning a justice so harsh towards its criminals "that there is the possibility sometimes of doing innocents in." ${ }^{36}$ In addition, the general praise of the Court's decision did not win over all the media. L'Humanité, the French Communist party newspaper, dedicated a very short article to abolition and-although there was an article on the Buffet-Bontems case on the same page-no comparison was drawn between the two countries. While the Communist party was strongly opposed to the death penalty in 1972, the article denied the exemplarity of the American decision and asserted that actions were already taken to cancel the decision-a claim which was later revealed to be correct. ${ }^{37}$ In the same manner, the 585 prisoners benefited only "in some way" from the decision, meaning, they were probably not going to be spared in the long run. ${ }^{38}$ Far more preoccupied with the denunciation of the Vietnam war, l'Humanite refused to abandon its antiAmericanist discourse. Even if the United States appeared to be heading down the right path, it could not stand as an example for France to follow. The exception that confirmed the rule, L'Humanité remained distinct from the rest of the French media.

11 The French reception of the 1972 Supreme Court decision evinced the rise of an international discourse on the death penalty's abolition. By conjuring up the notion of "civilization" or commenting on the American decision's exemplarity, the media refused to limit the debate to its national significance. Moreover, by not only reporting the news but also analyzing it as a portent of inevitable progress, a sign that the world was inexorably heading toward abolition, the journalists transformed the decision into a symbolic event that could have an impact on French politics.

IV The Reinstatement of the Death Penalty in the US 
12 Surprisingly, the French media did not pay much attention to the American reinstatement of the death penalty. While the Supreme Court upheld the more rationalized sentencing procedure in a set of three 1976 decisions collectively known as Gregg v. Georgia, thereby reopening the door to the death chamber in America, Le Monde was the only newspaper to analyze-and strongly denounce-the decision. ${ }^{39}$ If the national newspapers had regarded the United States as an example in 1972, this step back comforted the traditional French criticism toward the American penal system. Considering the consequences of the decision, Le Monde argued that "one should keep in mind the imponderable nature of American psychology ... it is ... obvious that the great majority of Americans still believe in the deterring and expiatory virtues of capital punishment despite the unceasing abolitionist campaigns." ${ }^{40}$ Americans appeared widely influenced by rising crime rates and thereby supported a reinstatement of a harsh and severe penal system. The overall absence of reaction in the press could also be explained by the general abolitionist stance advocated by most national mainstream newspapers. A piece of information going against what was believed to be a world-wide trend toward abolitionism did not serve the cause well. In contrast to the 1972 decision, which journalists exploited to undermine the pro-death penalty cause, the 1976 decision went almost unnoticed, as if irrelevant in a French context that saw the number of executions declining. ${ }^{41}$

13 Conversely, when Gary Gilmore-the first convict put to death in ten years in the United States-was executed in 1977 the French press showed a deep interest. Once again, a coincidence encouraged the journalists to adopt an international standpoint: three days after the Gilmore execution, the child-murderer Patrick Henry was condemned in France to life in prison, a momentous decision considering that public opinion was vehemently in favor of his execution. ${ }^{42}$ The two events therefore inverted the previous situation: while France was "de facto abolishing the death penalty" as pointed out by L'Express, the United States reverted to their former practice. ${ }^{43}$ The conditions were ripe for the setting up in the French media of a long-lasting opposition between a "barbaric" America and a reasoned France.

14 First, journalists once again exploited the Supreme Court's decision to inform the French abolition debate. However, this time the American reinstatement of the death penalty was not only used by the abolitionist side but also served as a strong argument in favor of retention. An anti-abolitionist law professor, Jean-Claude Soyer, took advantage of the simultaneous events to draw subtle comparisons between the two penal systems in a Le Figaro op-ed. Probing one by one the traditional arguments in favor of abolition, he denied the allegation that the death penalty is a more terrible "torture" than life imprisonment. To support his claim, he reminded his readers that "currently, in the United States, some inmates are struggling to obtain their executions." Although Soyer didn't explicitly name Gilmore, it was obvious to most readers that he alluded to the recently executed American. Indeed, Gilmore had not only refused the appeals filed by his lawyers to prevent his execution but also his last months in jail were disrupted by two attempted suicides. ${ }^{44}$ Soyer then concluded his article: "We are right to believe in the efficiency of the death penalty, and therefore to retain its use as a weapon against crime .... Besides, French people are favoring it in a large majority (as do Californians, a people that it would be difficult to characterize as backward-looking)." ${ }^{45}$ Soyer was probably alluding to the November 1972 California referendum on "proposition 17" which intended to reinstate the death penalty, and 
which was accepted by a large margin. Building upon the reputation of California (and more generally, the United States) as a symbol of progress and innovation, Soyer hoped to avert the traditional abolitionist critique that equated the death penalty with barbaric societies. The allusion was discreet, but it demonstrated the argument's latent presence in French media discourse.

15 L'Humanité was undoubtedly the newspaper that epitomized this opinion. Considered anachronistic in a civilized society, the death penalty was deemed a "medieval practice." In order to impress the readers and link the execution to an unfair and barbaric tradition, the journalist described Gilmore's last moments in terms of hunting: "Vile execution in the United States: Gary Gilmore was shot yesterday with a big game gun" yelled the headline. Although the method was chosen by Gilmore himself, the firing squad was represented as a shocking reversion to primitive times. Gilmore's body "collapsed like big game in the jungle" related the journalist. Interestingly, while the United States appeared as a backward country locked in the past, L'Humanité condemned its pervasive mass media as "experts in the art of [public] manipulation" as well as the execution's financial exploitation via filming, both symbolically corrupting the apparent characteristics of a modern and innovative nation. The ambiguous denunciation again addresses the paradoxical nature of anti-American discourses. For the journalist, there was no contradiction to ponder; the United States was a powerful country that lacked morality and judgment. Like Soyer, l'Humanité alluded to the commonalities of the French and American systems, and used the comparison to condemn both countries' practices. Examining American police accusations against the excessive clemency displayed by judges, the journalist cried out: "Mr. Poniatowski hasn't invented anything!" Michel Poniatowski, French minister of the interior and an avowed retentionist, had indeed recently taken a stand on the issue, advocating for the death penalty in the Henry case and supporting similar views held by the police officers union. ${ }^{46}$ The journalist also fustigated the "game of cat and mouse" present in the numerous deferments of Gilmore's execution. He asserted that binding the inmates' life to the stroke of a pen was very much like "the presidential power to pardon." ${ }^{47}$ By hinting at the French system of pardon, the journalist effectively condemned the two systems in the same tirade.

16 While in 1972 the communist newspaper was alone in its sharp criticism of the American penal system, it did not stand out among the French media in 1977. Journalists largely denounced Gilmore's execution and attached special attention to what seemed an outdated method of execution: the firing squad. Coined a "macabre soap opera" in the news, the Gilmore execution was scrutinized in its most graphic aspects, such as the fact that Gilmore had declined to wear the scarf over his eyes but was obliged to by the law. ${ }^{48}$ Although Le Monde didn't indulge in the execution's gruesome details, the newspaper compared the death penalty to a "barbaric lottery" and denounced Gilmore's execution in $1977 .{ }^{49}$ These reports bear witness of the revival of a French discourse censuring "barbaric" America. The guillotine was not yet put away in a museum. Nevertheless, the French national press was already undertaking the task of building a strong discourse against the death penalty.

17 Indeed, in 1977-the last year that witnessed an execution in France-most of the media declared the impending abandonment of capital punishment..$^{50}$ This was not a novelty: as early as 1972, several newspapers hinted at the coming disappearance of the infamous practice. Le Nouvel Observateur, sharply condemning the Buffet-Bontems death 
sentence, warned Pompidou that his failure to pardon the two criminals would "revive the death penalty he ha[d] de facto abolished since his arrival at the Elysée." ${ }^{51}$ Similarly, L'Express pointed out the fact that, according to abolitionists, if Pompidou granted clemency it "would mean the death of the death penalty." 52 Already hinted at in 1972, abolition had become more of a priority by 1977. Indeed, in most newspaper accounts, Patrick Henry's life imprisonment sentence amounted to an unofficial abolition. Echoing the words of one of Patrick Henry's lawyers, Robert Bocquillon, who, quoted in L'Express, solemnly declared the "de facto abolition of the death penalty in France," French media anticipated legal abolition..$^{53}$ Most symbolic was the title of the article that Le Monde ran on the event: "The death of a penalty?" If killing a child was not a capital crime anymore, reasoned the journalist, then the penalty was in serious danger of disappearance. Le Monde was not the only newspaper to run wordplays for the occasion: "Dead, the death penalty?" wondered Le Nouvel Observateur. While the journalist answered "not yet", he still emphasized the "great blow it just received." 54 This anticipation of the 1981 law, clearly present from 1972 onwards, might explain how a "broadly supported moral orthodoxy against the death penalty", as David Garland put it, was so firmly established shortly after the actual abolition. ${ }^{55} \mathrm{As}$ Evi Girling recently noted, few scholars have sought to understand the process through which the death penalty in Europe-and most spectacularly in France-"remains effectively beyond political will and imagination." ${ }^{56}$ In France, part of the reason seems to lie in the forceful denunciation that most French media engaged in throughout the 1970s.

V Conclusion

18 By gradually portraying France as a "de facto" death-penalty-free state, French media accustomed public opinion to the idea of an inevitable abolition. In the meantime, they developed a semi-official discourse that represented the guillotine as an aberration in French history. "Voltaire and Hugo's country" could no longer be associated with this infamous punishment. The American counter-example, starting in 1977, only helped in this process. As the "privileged Other of France," ${ }^{57}$ the country against which France had traditionally defined its identity, the United States allowed France to refine its distinctiveness around the death penalty issue. This resonates with David Garland's suggestion that scholars should attend to the "cultural role" of legal practices. Practices of punishment, asserts Garland, shape social meanings and social worlds and, by marking a difference between self and other, take on a symbolical dimension. ${ }^{58}$ This remark is especially important within the framework of international rivalries as it demonstrates how foreign affairs can sometimes shape domestic policy. Legal scholar Richard Primus has shown how much American policy during the Cold War was influenced by the need to distinguish itself from the Soviet Union and Nazi Germany. ${ }^{59}$ Similarly, the American reinstatement of the death penalty reinforced French abolitionism.

19 Starting in the mid-1970s, the death penalty therefore served as a cultural signifier for France to distinguish itself from the United States, thereby preserving and shaping its identity. While Evi Girling has dealt with this identity-building process in Europe, she has only concentrated on the 1990s and 2000s. ${ }^{60}$ Yet, to be accurate about the origins of the opposition between a death-penalty free Europe and a barbaric America, one should also take into account the 1970s. Although for a short period the United States embodied an example to follow, the reconstitution of a critical discourse toward the transatlantic neighbor was quickly undertaken following the Supreme Court's 1976 
decision. In 1977, while Gilmore's execution inaugurated a new divide between the United States and Europe, the Henry trial ushered in the pervasive discourse on the "death of the death penalty." Anticipating the famous Mitterrand decision of 1981, French journalists played a major role in foreseeing and delineating the contours of a France free of its guillotine. In the meantime, they contributed to shaping an international discourse on penal practices and abolition that effaced geographical boundaries and encouraged a global appreciation of the significance of national decisions and events (particularly, of course, in America).

\section{BIBLIOGRAPHY}

Seth D. Armus, French Anti-Americanism (1930-1948): Critical Moments in a Complex History

(Lanham: Lexington Books, 2007)

Robert Badinter, L'abolition (Paris: Fayard, 2000)

Robert Badinter, Contre la peine de mort : écrits 1970-2006 (Paris: Fayard, 2006)

Robert Badinter, L'abolition de la peine de mort (Paris: Dalloz, 2007)

Stuart Banner, The Death Penalty: An American History (Cambridge \& London: Harvard University Press, 2002)

Thomas Bender, A Nation Among Nations: America's Place in World History (New York: Hill and Wang, 2006)

Thomas Bender, ed., Rethinking American History in a Global Age (Berkeley: University of California Press, 2002)

Jean-Michel Bessette, Il était une fois la guillotine (Paris: Alternatives, 1982)

Raymonde Carroll, Cultural misunderstandings: the French-American Experience (Chicago: University of Chicago Press, 1988)

Sandrine Costa, La peine de mort: de Voltaire à Badinter (Paris: Éditions Flammarion, 2001)

Frank Costagliola, France and the United States: The Cold Alliance since World War II (New York: The University of Rhode Island, 1992)

Council of Europe, ed., The Death Penalty. Beyond Abolition (Strasbourg: Council of Europe Publishing, 2004)

Anthony Daniels, "Sense of Superiority and Inferiority in French Anti-Americanism," in Paul Hollander, Understanding Anti-Americanism (Chicago: Ivan R. Dee, 2004), 65-83.

Eric Dior, Un couple infernal. Deux cent ans de francophobie et d'antiaméricanisme (Paris: Perrin, 2003)

Documentation Francaise, ed., L'abolition de la peine de mort (Paris: La Documentation Francaise, 1987) 
Eglise catholique - Conférence épiscopale française, Faut-il maintenir la peine de mort en France ?: éléments de réflexion / Commission sociale de l'Épiscopat (Paris: Éditions du Centurion, 1978)

Norbert Elias, The Civilizing Process: The History of Manners and State Formation and Civilization (Cambridge: Blackwell, 1994 [1939])

David Garland, The Culture of Control: Crime and Social Order in Contemporary Society (Oxford: Oxford University Press, 2001)

Pierre Guerlain, Miroirs transatlantiques: La France et les Etats-Unis entre passions et indifférences (Paris: L’Harmattan, 1996)

Jean Guisnel, Les pires amis du monde: les relations franco-americaines à la fin du XXe siecle (Paris: Stock, 1999)

Herbert H. Haines, Against Capital Punishment: The Anti-Death Penalty Movement in America, 1972-1994 (New York: Oxford University Press, 1996)

Roger Hood, The Death Penalty: A Worldwide Perspective (New York \& Oxford: Oxford University Press, 2002)

Jean Imbert, La peine de mort: Que Sais-Je? (Paris: Presses universitaires de France, 1993)

Richard Kuisel, Seducing the French. The Dilemma of Americanization (Berkeley: University of California Press, 1993)

D. Lacorne, J. Rupnik and M-F. Toinet, L'Amérique dans les têtes. Un siècle de fascinations et d 'aversions (Paris: Hachette, 1986)

Denis Lacorne, “The Barbaric Americans,” Wilson Quarterly 25 (Spring 2001): 51-53.

Julie Le Quand Sang, La loi et le bourreau: la peine de mort en débats (1870-1985) (Paris:

L'Harmattan, 2001)

Sylvie Mathé, L'antiaméricanisme at home and abroad (Aix-en-Provence: Publications de l'université de Provence, 2000)

Albert Naud, L'agonie de la peine de mort? (Paris: La Table ronde, 1972)

Jacques Portes, Une fascination réticente. Les Etats-Unis dans l'opinion française (Nancy: Presses Universitaires de Nancy, 1990)

Richard Primus, “A Brooding Omnipresence: Totalitarianism in Postwar Constitutional Thought," Yale Law Journal 106 (1996): 423-457

Jean-François Revel, L'obsession anti-américaine (Paris: Plon, 2002)

Philippe Roger, The American Enemy: a Story of French Anti-Americanism (Chicago: University of Chicago Press, 2005)

Austin Sarat, ed., The Killing State. Capital Punishment in Law, Politics, and Culture (New York \& Oxford: Oxford University Press, 1999)

Austin Sarat and Christian Boulanger, eds., The Cultural Lives of Capital Punishment.

Comparative Perspectives (Stanford: Stanford University Press, 2005)

Edwin D. Schoonmaker, Our genial enemy, France (New York : R. Long \& R.R. Smith, 1932)

Carol Steiker, "Capital Punishment and American Exceptionalism," Oregon Law Review 81 (2002): 97-130 
Michel Taube and Benjamin Menasce, Lettre ouverte aux Américains pour l'abolition de la peine de mort (Paris: Manifeste Collection Édition L'Écart, 2000)

Moshik Temkin, The Sacco-Vanzetti Affair: America on Trial (New Haven: Yale University Press, 2009)

Laurence Thibault, La Peine de mort en France et à l'étranger (Paris: Gallimard, 1977)

Cécile Toqué Pichon, L'abolition de la peine de mort en France. La “ loi Badinter” (Paris:

Panthéon, 2006)

Jean Toulat, La peine de mort en question (Paris: Pygmalion, 1977)

James Q. Whitman, Harsh Justice: Criminal Punishment and the Widening Divide between America and Europe (New York: Oxford University Press, 2003)

Franklin E. Zimring, The Contradictions of American Capital Punishment (New York \& Oxford: Oxford University Press, 2003)

\section{NOTES}

1. Denis Lacorne. “The Barbaric Americans," Wilson Quaterly 25 (Spring 2001): 52.

2. The phrase is from James Whitman. See James Q. Whitman, Harsh Justice: Criminal Punishment and the Widening Divide between America and Europe (New York: Oxford University Press, 2003).

3. See for instance in bibliography: Whitman (2003), Zimring (2003), Garland (2001) and Steiker (2002). For a critique of the notion of "exceptionalism" and a reflection on transnational history, see Thomas Bender, A Nation Among Nations: America's Place in World History (New York: Hill and Wang, 2006).

4. The death penalty was abolished in Italy in 1948, in Finland and Germany in 1949, in Austria in 1968, in the United Kingdom in 1969, in Sweden in 1972, and in Portugal in 1976. See: Council of Europe, ed., The Death Penalty. Beyond Abolition (Strasbourg: Council of Europe Publishing, 2004), 7. On European abolitionism and the cultural construction of Europe as a death penalty-free zone, see Evi Girling, "European Identity and the Mission Against the Death Penalty in the United States." in Austin Sarat and Christian Boulanger, eds., The Cultural Lives of Capital Punishment. Comparative Perspectives (Stanford: Stanford University Press, 2005), 112-128.

5. See Cécile Toqué Pichon, L'abolition de la peine de mort en France. La "loi Badinter". (Paris: Panthéon, 2006); Julie Le Quang Sang, La loi et le bourreau: la peine de mort en débats: 1870-1985 (Paris: L'Harmattan, 2001); Sandrine Costa, La peine de mort: de Voltaire à Badinter (Paris: Éditions Flammarion, 2001).

6. Between 1967 and 1976, there were no executions in the United States, while seven were performed in France.

7. Sarat \& Boulanger, The Cultural Lives, 1.

8. The newspapers reviewed for this paper were: Le Monde, Le Figaro, Le Nouvel Observateur, L'Express, Le Point, La Croix, Le Canard Enchaîné, L'Humanité, France Soir, as well as the television news of channel 1 and 2. Clippings were also consulted from Minute, L'Aurore, Est Éclair, Le Petit Parisien, Libération-Champagne and Politique hebdo, available in Documentation Francaise, ed., L'abolition de la peine de mort (Paris: La Documentation Francaise, 1987). Most newspapers reviewed were either in favor of abolition or neutral. Some were adamantly retentionist (for instance Minute, politically 
on the far right) while others only showed support for the death penalty during the Buffet and Bontems case (the local press in particular).

9. Lacorne, "The Barbaric", 51.

10. Stuart Banner, The Death Penalty: An American History (Cambridge \& London: Harvard University Press, 2002), 231. The quotation is from the New Republic.

11. The gradual decline in executions and the rise of abolitionist voices within and without the United States also played a role in the decision. See Herbert H. Haines, Against Capital Punishment: The Anti-Death Penalty Movement in America, 1972-1994 (New York \& Oxford: Oxford University Press, 1996), 21.

12. Le Monde, July $1,1972,1$. The French president, Georges Pompidou, had commuted all death sentences following his election in 1969.

13. Toqué Pichon, L'abolition, 62.

14. Le Monde ran on its front page two articles-one on the Supreme Court decision, the other on the combined analysis of the American situation and Buffet and Bontems' death sentences-under the same overarching title: "A Few Hours Away," Le Monde, July $1,1972,1$.

15. Le Figaro, June 30, 1972, 1.

16. La Croix, July 1, 1972, 1; Le Monde, July 1, 1972, 1.

17. Le Monde, July 1, 1972, 12.

18. Le Point, December 4 1972, 64. The article was published shortly after the execution of Buffet and Bontems, which was performed on November 281972.

19. Norbert Elias, The Civilizing Process: The History of Manners and State Formation and Civilization (Cambridge: Blackwell, 1994 [1939])

20. La Croix, July 1, 1972, 1; Le Figaro, June 30, 1972, 1.

21. See Jurgen Martschukat, "Nineteenth-Century Executions as Performances of Law, Death, and Civilization," in Sarat and Boulanger, The Cultural Lives, 49-91.

22. The common platform of the Left released in June 1972 condemned the death penalty. The Catholic church eventually denounced it in an article published on January 23 1977, in the Observatore Romano. (Julie Le Quang Sang, La loi et le bourreau: la peine de mort en débats (1870-1985) (Paris: L'Harmattan, 2001), 119 and 128).

23. A recent example of this argument can be found in The Council of Europe, The Death Penalty: Beyond Abolition (Strasbourg: Council of Europe Publishing, 2004), 8, where the death penalty was declared "not to have a place in a civilized society."

24. Toqué Pichon, L'abolition, 118-120.

25. Mende is a French commune in the department of Lozère.

26. Le Monde, July 1, 1972, 1. See also Le Figaro, November 29, 1972, 5.

27. L'Express, July 3-9, 1972, 38.

28. Le Canard enchaîné, June 5, 1972, 4.

29. France Soir, July 1, 1972, 3.

30. For a reflection on the "ethical war" between France and the United States, see Lacorne, "The Barbaric", 53.

31. Moshik Temkin, The Sacco-Vanzetti Affair: America on Trial (New Haven: Yale University Press, 2009).

32. Banner, The Death Penalty, 242-243. For an account of international reactions to the Sacco-Vanzetti affair, see Temkin, The Sacco-Vanzetti Affair.

33. Le Monde, July 1, 1972, 1.

34. See in bibliography Portes (1990), Rupnik and Toinet (1986), Revel (2002), Mathé (2000), Roger (2005). 
35. Denis Lacorne, "Anti-Americanism and Americanophobia: A French Perspective," lecture available on the Science Po website: http://www.ceri-sciencespo.com/archive/ mars05/artdl.pdf (accessed 6 January 2010).

36. Le Canard enchaîné, June 5, 1972, 4.

37. Banner, The Death Penalty, 268-271; L'Humanité, June 30, 1972, 1.

38. L'Humanité, June 30, 1972, 1; 585 American prisoners were on death row at the time of the decision. . Philippe Roger contends that anti-American discourse was adopted by the French Left shortly after World War II. The condemnation of the United States became a constant in communist discourse, as exemplified in this case. Philippe Roger, The American Enemy: a Story of French anti-Americanism (Chicago: University of Chicago Press, 2005), 327.

39. Banner, The Death Penalty, 267-305; France Soir ran a short article on the decision as well, see France Soir, July 4, 1976, 3.

40. Le Monde, July 4, 1976, 2

41. No execution had taken place in 1974 and 1975 as Valery Giscard d'Estaing had commuted most death sentences to life imprisonment. See Julie Le Quang Sang, La loi et le bourreau, 258.

42. Toqué Pichon, L'abolition, 66.

43. L'Express, January 24-30, 1977, 56.

44. See Le Figaro, January 18, 1972, 11.

45. Le Figaro, January 18, 1977, 11. Soyer had already used the California situation to support the retentionist side shortly after the execution of Buffet and Bontems in an op-ed published by Le Figaro, November 29, 1972, 5.

46. Michel Poniatowski had made his opinion clear on the radio station RTL on February 19 1976. La Documentation Francaise, L'abolition de la peine de mort, 38.

47. L'Humanité, January 18, 1977, 10.

48. January 17, 1977, Channel 2, Journal télévisé, 20 h.

49. Le Monde, July 4, 1976, 2; Le Monde, January 18, 1977, 13.

50. There were two executions in 1977. The last convict executed was Hamida Djandoubi on September 101977.

51. Emphasis in the original. Le Nouvel Observateur, November 20-26, 1972, 40.

52. L'Express, November 27-December 3, 1972, 75.

53. L'Express, January 24-30, 1977, 56.

54. Le Monde, January 23-24, 1977, 28; Le Nouvel Observateur, January 24, 1977, 22. L'Aurore and L'Est Éclair used the same device to convey the imminence of abolition: "Is it the abolition of the death penalty?" asked the journalist in Est Éclair while L'Aurore wondered if "the members of the Troyes Jury ha[d] condemned the Executioner." L'Aurore, January 22-23, 1977, 16; L'Est Éclair, January 21, 1977, 1.

55. Franklin E. Zimring, “The Executioner's Dissonant Song: On Capital Punishment and American Values," in Austin Sarat, ed., The Killing State. Capital Punishment in Law, Politics, and Culture (New York \& Oxford: Oxford University Press, 1999), 139.

56. Girling, "European Identity," 112.

57. Pierre Guerlain, Miroirs transatlantiques: La France et les Etats-Unis entre passions et indifférences (Paris: L'Harmattan, 1996), 7.

58. Austin Sarat, "The Cultural Life of Capital Punishment: Responsibility and Representation in Dead Man Walking and Last Dance," in Sarat, The Killing State, 22. 59. Richard Primus, "A Brooding Omnipresence: Totalitarianism in Postwar Constitutional Thought," Yale Law Journal 106 (1996): 423. 
60. Girling, "European Identity."

\section{ABSTRACTS}

This article challenges the current scholarship on the history of the death penalty and its abolition by adopting a transatlantic framework and debunking the popular contemporary conception of the "Barbaric Americans" against the "civilised" anti-death penalty French. The article focuses on the short period in the 1970s during which American executions were halted by the Supreme Court, while France was still putting prisoners to death in cases that were widely debated in public opinion. By observing the French media's reactions to the two major decisions taken by the Supreme Court in the 1970s and their direct consequences, this essay analyzes not only the French gaze on American practices but also how these American decisions were manipulated by the journalists to stoke the French debate about abolition.

\section{AUTHOR}

\section{ELSA DEVIENNE}

Elsa Devienne, EHESS (Center of North-American Studies, CENA), Paris 